\title{
Physicochemical Properties of Tamarind (Tamarindus indica) Seed Polysaccharides
}

\author{
Mohamed $\mathrm{HA}^{1^{*}}$, Mohamed $\mathrm{BE}^{2}$ and Ahmed $\mathrm{KE}^{2}$ \\ ${ }^{1}$ Food Industries Research Department, Industrial Research and Consultancy Center, Khartoum North, Sudan \\ ${ }^{2}$ Department of Food Science and Technology, University of Khartoum, Sudan
}

\begin{abstract}
The polysaccharides of two samples of Tamarindus indica (Tamarind) seed; namely Light brown (LB) and Dark brown (DB), were extracted and studied for their physicochemical and functional properties. The physiochemical properties were determined and compared to those of commercial pectin to investigate their potentials as probable substitute of pectin. The two polysaccharide extracts were similar in most of the physical properties such as solubility in hot water, $\mathrm{pH}$, and refractive indices as compared to commercial pectin. The intrinsic viscosity, molecular weights and equivalent weights were similar in both extracts and higher than that of commercial pectin. The polysaccharides were the major components in the extract comprising $88.85 \%, 85.21 \%$ and $92.43 \%$ for LB, DB and commercial pectin, respectively. The tamarind seed polysaccharides form gels over a wide $\mathrm{pH}$ range in the presence of sucrose with or without acid and base, while commercial pectin forms gels over a narrow range (acidic) in the presence of sucrose. Although the protein levels in the polysaccharides were higher compared to commercial pectin, their gel formatting ability was found more applicable as compared to commercial pectin. This indicated that the protein level did not interfere with gel formation. The functional properties of both extracts, as a gelling agent, indicated that polysaccharides of both samples contained residual amount of uronic acid, no galacturonic acid, no acetyl group, small amount of methoxyl group, and high degree of estrification. The commercial pectin, however, contained a high level of uronic acid and relatively low degree of estrification. The high performance liquid chromatography showed that the two polysaccharide extracts contain pentose sugars (xylose and arabinose) and hexose sugars (glucose and galactose). The molar ratios of these sugars were 2:1:3:1 in both extracts. Commercial pectin contains similar sugars but with fructose instead of xylose.
\end{abstract}

Keywords: Tamarind seed polysaccharides; Pectins; Methoxyl contents; Galacturonic acid; Gel formation

\section{Introduction}

Tamarindus indica L, (Tamarind) a member of the family Leguminosae (Fabaceae), is native to dry Savanna of tropical Africa [1]. It is an important woody perennial fruity species known for its adaptability to variable climatic and edaphic conditions and for fruit production [2]. In Sudan, the tamarind grows wild on sandy soils and near Khors (water cources) in short grasses Savanna in Kordofan, Darfur, Blue Nile, Bahr ElGhazal [3]. India is the main producer and consumer of tamarind in the world [4]. The edible pulp of ripe fruit is used as a flavouring agent in cooking, soups, jams chutneys, sauces, and juices and the preparation of beverage [5]. In Sudan, the tamarind pulp is used as a beverage [6] and the seeds are discarded.

Pectin, which is chemically similar to cellulose, may be thought of as the "glue" that holds the cellulose together in the cell walls of plants. Pectin and cellulose are both polysaccharides, but pectin is primarily a-linked polygalacturonic acid (partly esterified with methyl ester) in which rhamnose may be found, and cellulose is essentially a polymer chain made up of b-1,4 linked sucrose units with no esterification. Not all plant materials are rich in pectin. The oldest pectin source is apple pomace left over from juicing. The most common source of pectin nowadays is from citrus peel, primarily lemon-but lime, orange and grapefruit may also be used. Novel sources of pectin include sugar beets and sunflower heads, but these are not, at the moment, commercially significant. In order to qualify as pectin, the anhydro-galacturonic acid must make up at least $65 \%$ of the ash-free dry matter in pectin sold as a commercial product [7].

Jam is one of the important fruit products with considerable economic and dietary importance in Sudan [8]. The pectin used in jam making is imported as there is no pectin industry yet in Sudan $[9,10]$ so more attention should be directed towards utilization of pectin obtained from local substitutes. From this point of view, the agricultural by-product like tamarind seed kernel can be used as a cheap source for functional food to increase the added value of tamarind seeds. Most researches, carried out in Sudan on tamarind, were on the pulp and for medicinal purposes [11] the seed was found to be rich in protein, sugar and potassium, thus can suffice the human needs and was consumed as famine food. Research concerning the chemical, technological and usage of tamarind kernel in Sudan are scarce. The aim of this study was to extract polysaccharides from tamarind kernel and study its physicochemical and functional properties compared to commercial pectin.

\section{Material and Methods}

Two samples of tamarind seeds; light brown (LB) and dark brown (DB),one kilogram each were obtained from Ali Ibrahim shop for tamarind juice. Pectin was obtained from Saeed Food Industry Factory. All chemicals and reagents used were of analytical grade.

Samples were prepared according to the method described by Ghose and Krishna [12].

*Corresonding author: Huda Mohamed, Food Industries Research Department Industrial Research and Consultancy Center, Khartoum North, Sudan, E-mail dr.huda6616@yahoo.com

Received April 01, 2015; Accepted April 21, 2015; Published April 28, 2015

Citation: Mohamed HA, Mohamed BE, Ahmed KE (2015) Physicochemical Properties of Tamarind (Tamarindus indica) Seed Polysaccharides. J Food Process Technol 6: 452. doi:10.4172/2157-7110.1000452

Copyright: (c) 2015 Mohamed HA, et al. This is an open-access article distributed under the terms of the Creative Commons Attribution License, which permits unrestricted use, distribution, and reproduction in any medium, provided the original author and source are credited. 
Whole seeds of tamarind were sun dried, and the immature and damaged seeds were discarded. The mature whole seeds were then soaked in sodium hydroxide solution (10\%) for $30 \mathrm{~min}$ then crushed and washed with water several times. The crushed seeds were dried, grounded into powder to pass through a 60 -mesh size. The powder was then divided into two portions and kept in plastic containers at room temperature. One part was used for proximate analysis where the other part was reserved for polysaccharides extraction.

\section{Proximate analysis}

Determination of moisture, protein, fat, ash, and crude fiber were carried out in triplicate.

The moisture content was determined by weighing the kernels before and after drying in an oven at $105^{\circ} \mathrm{C}$ for 3 hours [13]

The nitrogen content was estimated by the micro- Kjeldahl method as modified by Cocon and Dian [14], and then crude protein was calculated by multiplying the $\mathrm{N}$ value with the factor 6.25 [15].

The fat content was determined by extracting the sample with ether in sohxlet apparatus for 16 hours [16].

The ash content was calculated by the method mentioned in AOAC [16]. The carbohydrate content was obtained by difference.

All proximate results were expressed as a percentage of the weight of samples analyzed.

\section{Extraction of tamarind seed polysaccharide}

The tamarind gum was extracted from the powder kernel by Khullar et al. [17] method.), in three batches at laboratory scale. To 200 grams of tamarind kernel powder, $2000 \mathrm{ml}$ of cold distilled water was added and slurry was prepared. The slurry was poured into $2400 \mathrm{ml}$ of boiling distilled water and boiled for 20 min with stirring in a water bath. The resulting thin clear solution was kept overnight so most of the protein and fiber settle down. The solution was then centrifuged at 5000 $\mathrm{rpm}$ for $20 \mathrm{~min}$. The supernatant was separated and poured into twice the volume of absolute ethanol with continuous stirring. The precipitate was pressed between cheese cloth and the product was washed with absolute ethanol, diethyl ether and petroleum ether. The material is then dried at $50-60^{\circ} \mathrm{C}$ under vacuum, then ground and sieved and stored for further purification.

\section{Physical properties}

The solubility and refractive index of polysaccharides were determined according to the method of the AOAC [16] and viscosity by the method of Gidley et al. [18].

The methods described by Owen et al. [19] were used for the analysis of pectin. Methods of analysis used for polysaccharide were those mentioned by Marlino [20].

\section{Chemical properties}

pH-value: The method described by $\mathrm{mts}$ was used for the determination of the $\mathrm{pH}$. A $1 \%$ aqueous solution of $\mathrm{LB}$ and $\mathrm{DB}$ polysaccharides and pectin were prepared and measured using a Beckman Zeromatic $\mathrm{pH}$ meter at room temperature.

Acetyl content: The acetyl content of the polysaccharide samples and the pectin were determined by a hydroxamine acid colour reaction [21].

Equivalent weight: The equivalent weight was calculated as follows Owens et al. [19]:

\section{Equivalent Weight $\quad=\quad$ Weight of sample $(\mathrm{mg})$ meq. Of sodium hydroxide}

where: meq. of sodium hydroxide $=$ normality $\times$ titre value

This titre is known as initial titre (IR) or free acid titre.

Uronic acid percentage: It was calculated by multiplying by 100 and dividing the apparent equivalent weight of the sample as follows:

Uronic acid $=\underline{194} \times \underline{100}$

Eq. weight

Methoxyl content: The methoxyl was determined according to Owens et al. [19] as follows:

Methoxyl content

$$
=\frac{\text { meq. of } \mathrm{NaOH} \times 31 \times 10}{\text { Weight of sample }}
$$

The degree of estrification and anhydrouronic acid: Content were calculated as follows:

$$
\text { Degree of esterification }=\frac{\mathrm{ST} \times 100}{\mathrm{ST}+\text { corrected IT }}
$$

The IT was corrected for ash alkalinity.

$$
\text { Anhydrouronic acid content (AUA) } \quad=\underline{176 \times 100}
$$

\section{Where}

$\mathrm{Z}=$ Weight of sample meq. of alkali for free acid + meq. of alkali for methoxyl

Sugar composition: Acid hydrolysis of the three samples was done according to the method adopted by Balabon [22]. Separation of sugars was done by high performance liquid chromatography (HPLC). Using HPLC system (HPLC UFLC, Shimadzu, Japan), with refractive index detector (RID - 10A), coloum ShodexAsahipak (type $\mathrm{NH}_{2} \mathrm{P}-504 \mathrm{E}$ ), mobile phase ( $175 \mathrm{ml}$ acetonitrile $+25 \mathrm{ml}$ water), oven temperature $30^{\circ} \mathrm{C}$, and column temperature $30^{\circ} \mathrm{C}$. Analyses were performed at ambient room temperature $\left(30^{\circ} \mathrm{C}\right)$, and the flow rate maintained at 1 $\mathrm{ml} / \mathrm{min}$. The retention times of the monosaccharide were monitored using differential refractometer (RID - 10A). The retention times were compared to those determined using D-glocose, D-galactose, D-xylose and L-arabinose (Sigma chemical Co. Ltd.) as standards. The area percentage of each peak was calculated by Shimazduprogramme which is connected with RI detector (RID - 10A). The sugar percentage was calculated as follows:

\section{Component sugar (i) $=$ Area percentage of component $(\mathrm{i}) \times 100$}

\section{Total area percentage}

\section{Gel formation, strength and setting rate}

The gel formation was carried according to the method described by Bhattacharya et al. [1]. One gram of the sample in each case was added to $22 \mathrm{~g}$ of sucrose and stirred well with $30 \mathrm{ml}$ distilled water. About $5 \mathrm{ml}$ of 3\% citric acid was then added in a beaker and boiled for $15 \mathrm{~min}$. In a second scenario, $5 \mathrm{ml}$ of $3 \%$ sodium citrate was added instead of citric acid. Without addition of acid and base in the third scenario only the samples with sugar and water. All these scenarios were done in triplicate (Figure 1). 
Gel strength was measured by the knife raising method similar to that suggested byRao [23]. About $50 \mathrm{ml}$ of gel suspension prior to setting was poured into jelly glass containing a knife and allowed to cool at $24^{\circ} \mathrm{C}$, for 24 hours. The relative gel strength was compared with standard jelly of pectin. Gel strength was reported as the time required raising the knife from the bottom of the $50 \mathrm{ml}$ jelly of $3 \mathrm{~cm}$ thickness by a weight of $50 \mathrm{~g}$ applied by Lever system.

The gel setting time was determined according to Rao [23]. About $50 \mathrm{ml}$ of gel suspension prior to setting was poured into $100 \mathrm{ml}$ beaker at room temperature $\left(28-30^{\circ} \mathrm{C}\right)$ and the time required for complete setting of the jelly was noted using stop watch. Complete setting was judged by inverting the beaker by pressing with the finger and by scooping with a spoon. Triplicate observations were made.

\section{Sensory evaluation of prepared jellies}

The gels were prepared from dark and light brown seeds and pectin in three scenarios (A- acid, B- base and S- sugar only). Sensory evaluation was conducted using a panel of 20 persons. Trained panelists evaluated 7 samples of gels for appearance, texture, taste and flovour, using ranking scale of 1 to 10 .

\section{Statistical analysis}

Sensory evaluation was assessed by randomized block design and analysis of variance (ANOVA) as shown by Scendecor and Cochran [24] and the least significance difference (LSD) was used to separate the means.

\section{Results and Discussion}

The moisture content, on fresh weight basis, of the two seed samples (Table 1) was higher than the value of $9.4 \%$ estimated by Marangoni et al. [25], and lower than the range $11.4 \%-22.7 \%$ reported by Ishola et al. [26], Bhattachanya et al. [27] and Morad et al. [28]. The protein contents of two samples was in agreement with the results of $21-25 \%$ reported by Leaky and Yusuf et al. [29] and higher than the values of $(15.5 \%, 17 \%)$ respectively. The oil percentage of the LB sample lied within range of

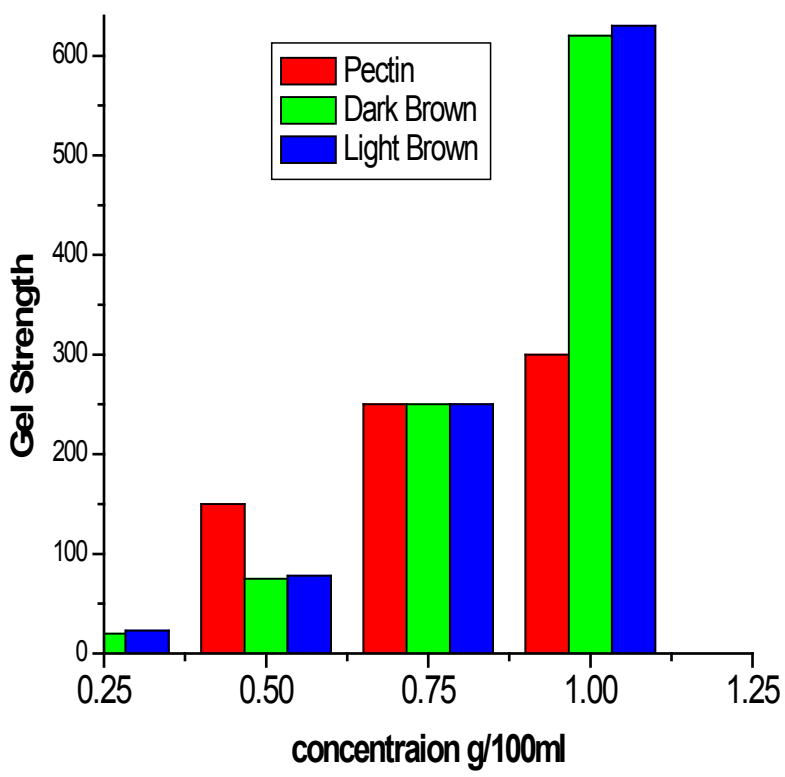

Figure 1: Effect of polysaccharides (LB and DB) and commercial pectin concentration on gel strength.

\begin{tabular}{|l|l|l|}
\hline \multirow{2}{*}{ Parameters (\%) } & \multicolumn{2}{|c|}{ Seed Sample } \\
\cline { 2 - 3 } & Light Brown (LB) & Dark Brown (DB) \\
\hline Moisture & $10.99 \mathrm{~b} \pm 0.1002$ & $11.21 \mathrm{a} \pm 0.0058$ \\
\hline Protein & $20.23 \mathrm{~b} \pm 0.5658$ & $23.75 \mathrm{a} \pm 0.0839$ \\
\hline Oil & $3.90 \mathrm{a} \pm 0.0500$ & $3.17 \mathrm{~b} \pm 0.0462$ \\
\hline Ash & $2.50 \mathrm{a} \pm 0.0000$ & $2.17 \mathrm{~b} \pm 0.0577$ \\
\hline Fiber & $3.08 \mathrm{a} \pm 0.0493$ & $2.51 \mathrm{~b} \pm 0.0058$ \\
\hline Carbohydrate (by difference) & $59.303 \mathrm{~b} \pm 0.4041$ & $57.33 \mathrm{a} \pm 0.2452$ \\
\hline
\end{tabular}

Seed colour: $\mathrm{LB}=$ Light brown and $\mathrm{DB}=$ Dark brown respectively Each value is a mean of three determinations.

Means followed by similar superscript letters in a column are not significantly different at $(P \geq 0.05)$

Table 1: Proximate chemical composition of the Tamarindus indica seed.

\begin{tabular}{|l|c|c|c|}
\hline \multirow{2}{*}{\multicolumn{1}{|c|}{ Parameter }} & \multicolumn{3}{|c|}{ Polysaccharide } \\
\cline { 2 - 4 } & Light Brown (LB) & $\begin{array}{c}\text { Dark Brown } \\
\text { (DB) }\end{array}$ & Pectin \\
\hline Intrinsic viscosity (dL/g) & 4.62 & 4.42 & 3.8 \\
\hline Molecular weight. & $7.3 \times 10^{4}$ & $7.1 \times 10^{4}$ & $6.3 \times 10^{4}$ \\
\hline Equivalent wt. & 5623 & 5697 & 803 \\
\hline Refractive index & 1.334 & 1.334 & 1.334 \\
\hline
\end{tabular}

Seed colour: $\mathrm{LB}=$ Light brown and $\mathrm{DB}=$ Dark brown respectively.

Table 2: Physical properties of Tamarind seed polysaccharides as compared to commercial pectin.

3.9\%-16.2\% estimated by Morad et al., Ishola et al. and Bhattacharya et al. [27]. While the DB sample gave $3.17 \pm 0.0462$ oil content which was lower than LB sample.

The ash values were in agreement with the range 2.17\%-4.2\% reported by Moradet al., Isholaet al.and Battacharya et al. [27], but lower than $2.8 \%-4.58 \%$ reported by Marangoni et al. and Bhattacharya et al. $[1,25]$. The fiber content of the two samples was within the range of $0.7 \%-8.2 \%$ reported by Bhattacharya et al. and Leakey [1], but higher than the values of $2.33 \%, 8 \%$ mentioned by Marangoni et al. and Yusuf et al. [25]. The carbohydrate content in the two samples was similar to the values of $59.4 \%, 58 \%$ and $58.83 \%$ reported by Marangoni et al. and Yusuf et al. [25] and lower than the range of $65 \%-73.48 \%$ reported by Morad et al. [28], Ishola et al. [26], Bhattacharya et.al., [27] and Leakey [30]. The percentage of carbohydrates in the two samples was sufficient for the extraction, purification and subsequent characterization of the polysaccharide. Marathee [31] claimed that the carbohydrate in tamarind kernels is not less than $50 \%$. The two samples showed significant difference in all components of the approximate chemical composition.

The extraction yielded $34 \%$ polysaccharides for LB sample and $29 \%$ for DB sample. The results obtained for both samples differ from the findings of Kooimanwho reported 32\%, and findings of Morad et al. [28], Ishola et al. [26] and Bhattacharya et al. [1] who reported 59\% and higher than range of $20 \%-25 \%$ estimated by Khannaet al. [32]. These variations may be due to the extraction conditions and the varieties of the tamarind itself. Graham and Uan [33] and Marlett et al. [34] indicated that the yield of polysaccharide depends on the extraction condition (temperature and time).

The viscosity and average molecular weight of the polysaccharides LB and DB were remarkably higher than that of commercial pectin (Table 2) and slightly higher than the findings of Chakravorti et al. [35] who reported $5.5 \times 10^{4}$ molecular weight and $4.17 \mathrm{dl} / \mathrm{g}$ viscosity for tamarind seed polysaccharide and lower than the value $8.9 \mathrm{dl} / \mathrm{g}$ reported by Reid [36]. These differences may be attributed to the differences in temperature. The average molecular weight for the two 
samples was higher than that of the commercial pectin. The equivalent weights of $\mathrm{LB}$ and $\mathrm{DB}$ polysaccharides were higher than that of pectin, and this may be due to difference in their polymers. The refractive indices indicated the similarity of tamarind kernel polysaccharides and commercial pectin.

Polysaccharides of both $\mathrm{LB}$ and $\mathrm{BD}$, have the same moisture content $(3.81 \%$ and $3.80 \%)$ which was lower than $5.18 \%$ for commercial pectin (Table 3). A significant difference was obtained between the two samples (LB and DB) polysaccharide in protein content and ash, both were higher than the pectin used as control. There was no significant difference between the two samples in oil content and fiber content. There was significant difference obtained between the two samples of polysaccharides in carbohydrate content and the values were higher than the value of $74.94 \%$ obtained by Savur and Sreenivasan [37] and lower than $95.8 \%$ of Marlino [20].

The absence of acetyl group in the polysaccharides extracted from both samples was indicated by no red colour formation as shown in Table 4 while a value of $0.034 \%$ was obtained for citrus pectin. There was a difference in the methoxyl content in the polysaccharides of the two samples. While commercial pectin showed much higher

\begin{tabular}{|l|c|c|c|}
\hline \multirow{2}{*}{ Parameters (\%) } & \multicolumn{3}{|c|}{ Polysaccharide } \\
\cline { 2 - 4 } & Light Brown (LB) & Dark Brown (DB) & Pectin \\
\hline Moisture & $3.810 \pm 0.070$ & $3.800 \pm 0.000$ & 5.18 \\
\hline Protein & $3.900 \pm 0.000$ & $6.500 \pm 0.017$ & 1.24 \\
\hline Oil & $1.323 \pm 0.070$ & $1.360 \pm 0.540$ & Trace \\
\hline Ash Content & $1.043 \pm 0.060$ & $2.933 \pm 0.060$ & 1.90 \\
\hline Fiber & $1.007 \pm 0.010$ & $1.030 \pm 0.660$ & 0.13 \\
\hline Carbohydrate (by difference) & $88.850 \pm 0.600$ & $85.210 \pm 0.530$ & 92.43 \\
\hline
\end{tabular}

Seed colour: $\mathrm{LB}=$ Light brown and $\mathrm{DB}=$ Dark brown respectively.

Table 3: Chemical constituents of Tamarind seed polysaccharides compared to reference commercial pectin.

\begin{tabular}{|l|c|c|c|}
\hline \multirow{2}{*}{ Parameter } & \multicolumn{3}{|c|}{ Polysaccharide } \\
\cline { 2 - 4 } $\begin{array}{l}\text { Acetyl content } \\
\text { Hydroxamic acid }\end{array}$ & $\begin{array}{c}\text { No red colour } \\
\text { formed }\end{array}$ & $\begin{array}{c}\text { No red colour } \\
\text { formed. }\end{array}$ & $\begin{array}{c}\text { Red colour } \\
\text { formed. }\end{array}$ \\
\hline Titration & 0 & 0 & $0-034$ \\
\hline Methoxyl content & 0.124 & 0.062 & 8.82 \\
\hline Degree of esterification & 100 & 100 & 66.82 \\
\hline Uronic acid & 3.44 & 3.45 & 62.90 \\
\hline
\end{tabular}

Seed colour: $\mathrm{LB}=$ Light brown and DB= Dark brown respectively.

Table 4: Chemical properties of Tamarind seed polysaccharides and Commercial Pectin.

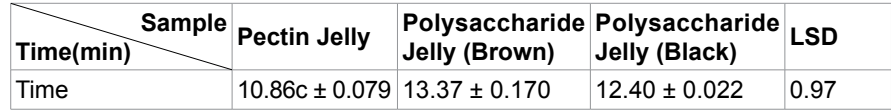

Table 5: Gel setting rate of Tamarind kernel polysaccharides and commercial pectin.

\begin{tabular}{|c|c|c|c|c|c|c|c|c|}
\hline \multirow{3}{*}{ Test } & \multicolumn{8}{|c|}{ Sample } \\
\hline & \multirow{2}{*}{$\begin{array}{c}\text { Pectin } \\
\text { A }\end{array}$} & \multicolumn{3}{|c|}{ LB } & \multicolumn{4}{|c|}{ DB } \\
\hline & & $\mathbf{S}$ & A & B & $\mathbf{S}$ & A & B & LSD \\
\hline Appearance & $1.959 \pm 0.033$ & $1.932 \pm 0.068$ & $1.931 \pm 0.068$ & $1.930 \pm 0.056$ & $1.911 \pm 0.068$ & $1.914 \pm 0.067$ & $1.880 \pm 0.070$ & 0.10 \\
\hline Texture & $3.960 \pm 0.030$ & $3.946 \pm 0.032$ & $3.923 \pm 0.031$ & $3.933 \pm 0.031$ & $3.903 \pm 0.031$ & $3.926 \pm 0.031$ & $3.894 \pm 0.030$ & 0.05 \\
\hline Taste & $1.966 \pm 0.021$ & $1.962 \pm 0.019$ & $1.956 \pm 0.019$ & $1.951 \pm 0.020$ & $1.936 \pm 0.020$ & $1.934 \pm 0.023$ & $1.915 \pm 0.027$ & 0.03 \\
\hline Flavour & $1.965 \pm 0.025$ & $1.956 \pm 0.027$ & $1.951 \pm 0.029$ & $1.946 \pm 0.027$ & $1.932 \pm 0.03$ & $1.928 \pm 0.029$ & $1.908 \pm 0.027$ & 0.05 \\
\hline Total score & $9.836 \pm 0.086$ & $9.536 \pm 0.407$ & $9.756 \pm 0.095$ & $9.536 \pm 0.407$ & $9.628 \pm 0.232$ & $9.701 \pm 0.092$ & $9.588 \pm 0.104$ & 0.31 \\
\hline
\end{tabular}

percentage of methoxyl content. Marlino [20] reported a value $0.02 \%$ and Damodaran and Rangachari [38] found 1.08\%. A similar value of $100 \%$ of esterification was obtained for LB and DB samples which were higher than commercial pectin. A similar value of $3.44 \%$ of uronic acid was obtained for samples of tamarind polysaccharides which agree with the value of 3.44\% reported by Savur and Sreenivasan [39] and lower than that of commercial pectin (62.9\%).

\section{Sugar identification}

The results indicated that the polysaccharides obtained from LB and DB samples contained two aldopentose sugar (xylose and arabinose) and two aldohexose sugars (glucose and galactose), while the commercial pectin contained ketohexose sugar (fructose) instead of the aldopentose sugar xylose. The presence of arabinose in the two polysaccharide agrees with the findings ofDamodran and Rangachari [38], Cremate and Rodrigves [40] and Marlino [20]. In addition to arabinose, galactose and xylose. McCready and Gee [41] and Mohamed [10] reported the presence of rhamnose in commercial pectin.

\section{Gel formation}

The tamarind Polysaccharides were able to form gels over a wide $\mathrm{pH}$ range in the presence of sucrose (with or without acid and base), while commercial pectin form gels over a narrow $\mathrm{pH}$ range (acidic) in the presence of sucrose. The maximum gel strength was obtained using concentration of $0.75 \%$ tamarind polysaccharides and commercial pectin, $65-70 \%$ sucrose concentration and $0.80 \%$ citric acid at $\mathrm{pH}$ range from 2.50-2.75. A significant difference $(P \geq 0.05)$ was obtained in the gel setting rate of gels made from the three gelling agents (Tables 5 and 6). The organoleptic evaluation of the gels showed that there were insignificant differences in appearance, texture, taste, and flavour under all conditions investigated for LB tamarind polysaccharide and commercial pectin. However, the appearance, taste, and flavour of the gels formed by DB tamarind polysaccharide under the base condition were significantly different. Although the gels made from commercial pectin obtained the higher panelists score $(9.836)$ compared to that made from LB and DB polysaccharide (9.756, 9.701, respectively), the statistical analysis showed insignificant difference.

\section{Gel setting rate}

The results indicated that the degree of esterification, rather than acetyl content and methoxyl content enhanced the gel formation. This result agrees with the findings of Savur and Sreenivasan [37], Ghose and Krishna [12] who attempted to relate gel-formation capacity to some factor like degree of esterification due to absences of methoxyl group in tamarind polysaccharides.

\section{Conclusion}

The tamarind seed, which is considered as waste can be converted into a useful agricultural by-product by extracting the kernels polysaccharide. The tamarind polysaccharides could be used as

$\mathrm{A}=$ Acid $\quad \mathrm{S}=$ Sugar $\quad$ Table 6: Sensory evaluation of pectin and polysaccharide jellies.

$\mathrm{A}=$ Acid $\quad \mathrm{S}=$ Sugar $\quad$ Table 6: Sensory evaluation of pectin and polysaccharide jellies. 
Citation: Mohamed HA, Mohamed BE, Ahmed KE (2015) Physicochemical Properties of Tamarind (Tamarindus indica) Seed Polysaccharides. J Food Process Technol 6: 452. doi:10.4172/2157-7110.1000452

Page 5 of 5

substitute for commercial pectin, thus reducing the import bill and the foreign currency expenditure. The findings of this study may provide a base for the possible industrial utilization of tamarind seed polysaccharide.

\section{References}

1. Bhattacharya S, Bal S, Mukherjee RK, Surendu B (1994) Functional and nutritional properties of tamarind (TamarindusIndica) kernel protein, Food Chemistry 49: 1-9.

2. El- Siddig, K, Ebert G, Liidders (1999) Tamarind (Tamarindus/ndica) A Review on multipurpose tree with promising future in the Sudan. J. Applied Botany 73 : 202-205.

3. El Amin HM (1990) Trees and Shrubs. Ithaca Press, UK.

4. Shankaracharya NB (1998) Tamarind- chemistry, technology and uses: a critical appraisal. J of Food Science and Technology 35: 193-208.

5. Siddhuraju P, Vuayakumari K, Janardhanay K (1995) Nutritional and antinutritional properties of the under exploited Legumes Cassia Laevigata Wild and Tamarindusindica L. J of Food Composition and analysis 8: 351-362.

6. Abu Zaid HA (1999) Biochemical evaluation of some Indigenous Plants of the Sudan. UK.

7. Joye DD, Luzio GA (2000) Process for selective extractionof pectinsfrom plant material by differential pH. Carbohydrate Polymer 43: 337-342.

8. Saeed A, El Tinay AH, Khattab AH (1975) Research note, Characterization of pectic substances in mango J Food Sci 40: 205-206.

9. El- Mubark A, Magboul B, Asma M (1977) Utilization of citrus waste as source of pectin in jam making. Sud J Ed Sci Technol 9: 55-59.

10. Mohamed HA (1999) Extraction, fractionation and characterization of pectic substances of grapefruit peels.

11. Mahmoud BM, Homeida MM (1994) Significant reduction in chloroquine bioavailability following co-administration with the Sudanese beverages aradaib, karkadi, and lemon. J Antimicrob Chemother 33: 1005-1009.

12. Ghose TP, Kishna S (1942) Decortications of tamarind seed. J.Indian Chem Soc. Ind. And News Ed5: 114

13. Janardhanan $M$ (1982) Composition and properties of seeds of tree legume TamarindusIndica. J Food Science 53: 1452- 1455

14. Cocon M, Diane VJ (1973) Analysis of protein and amino acid, Oxford University Press, London.

15. Jeanette MS (1987) Sorghum quality laboratory manual for use in West Africa Oxford. University Press, UK.

16. AOAC (1990) Association of Official Analytical Chemists. Official Methods of Analysis $20^{\text {th }} \mathrm{ed}$. Washington DC.

17. Khullar P, Khar RK, Agarwal SP (1998) Evaluation of guar gum in the preparation of sustained- relase matrix tablets. Drug Dev Ind Pharm 4: 1095-1099.

18. Gidley MJ, Lillford PJ, Rowlands DW, Lang P, Dentini M, et al. (1991) Structure and solution properties of tamarind seed polysaccharide, Carbohydrate. Research 214: 299-314.

19. Owens HS, McCready RM, Shepherd AP, Schultz TH, Pippen EL, et al. (1952) Methods used at western regional research laboratory for extraction and analysis of pectic materials. Bureau of Agricultural and Industrial Chemistry 340: 1-33.

20. Marlino SL (1989) Sorption of xyloglucan onto cellulose fibres.

21. McCready RM, Reeve RM (1955) Plant tissues analysis, test for pectin based on reaction of hydroxamic acid with ferric ion. J Agric Food 3: 260-262.
22. Balabon MG (2003) Hydrolysis of polysaccharide with $77 \%$ sulphuric acid for quantitaivesaccharification. Turk J Agric Fores 27: 361-365.

23. Rao PS (1948) Tamarind seed (Jellose Pectin) and its jellying properties. J Sci and Ind Res 68: 89-90.

24. Sendercor GW, Cochran WG (1996) Statistical Methods. Lowa State University Press, Ames. IA, USA

25. Marangoni A, Ali L, Kermasha S (1988) Composition and properties of seeds of the true legume Tamarindusindica. J Food Sci 53: 1452-1455

26. Ishola MM, Agbaji EB, Agbaji AS (1990) Chemical study of Tamarindusindica (Tsamiya) fruits grown in Nigeria. Journal of Science food and Agriculture 51 141-143.

27. Bhattacharya S, Bal S, Mukherjee RK, Bhattacharya S (1993) Some physical and engineering properties of tamarind (TamarindusIndica) seed. J Food Eng 18: $77-89$.

28. Morad MM, Magoli ELSB, Sedky KA (1978) Physicochemical properties of Egyptian tamarind seed oil. FetteSeifen Anstrichmittly 80: 357-359.

29. Yusuf AA, Mofio MB, Ahmed BA (2007) Proximate and mineral composition of Tamarindusindica Linn. Seed Science World J 2: 1-4.

30. Leakey BRR (1999) Potential for novel food products from agroforestry trees. A review. J Food Chemistry 66: 1-14.

31. Marathee RM (2002) Gelling behavior of polyose from tamarind kerne polysaccharides. Food Hydrocolloids 16: 423-426.

32. Khanna M, Dwived KA, Singh S (1997) Polyose from seeds of Tamarindusindica of unique property and immense pharmaceutical use in trends in carbohydrate chemistry 4: 97-81.

33. Graham HG, Uan P (1988) Extraction of soluble fiber. J Agric Food chem 36 494-497.

34. Marlette JA, Chesters JG, Longaere MJ, Bogdanske JJ (1989) Recovery of dietary fibre is dependent on the method of analysis. Am J Clin Nutr 50: 479485 .

35. Chakravorti IB, Nog S, McMillan WC (1963) Detrmination of molecular weight of tamarind Kernel polysaccharide. Indian J Technology 1: 216-217.

36. Reid TSG (1985) Cell wall storage of carbohydrate in seed "gums" and "hem celluloses". Advances in Botanical Research 11: 125-155

37. Savur GR, Sreenivasan A (1946) Tamarind seed pectin. Current Sci 15: 168

38. Damodran M, Rangachari S (1945) Tamarind seed pectin. Cur Sci 14: 203-204

39. Nanji HR, Savur GR, Sreenivasan A (1945) Tamarind seed "Pectin" Current Sci 14: 129-130.

40. Cremate, Alvones JA, Rodrigves Orozeo LR (1978)Polysaccharide study of the tamarind seed monosaccharide constituents. Rev. CENIC 9: 227-238.

41. McCready RM, Gee MJ (1960) Plant pectin analysis, Determination of pectic substances by paper chromatography. J Agr Food Chem 8: 510-513. 